Guido Alfani

Bocconi University, Dondena Centre and Stone Center on Socio-Economic Inequality

guido.alfani@unibocconi.it

Sonia Schifano

University of Luxembourg

sonia.schifano@uni.lu

\title{
Wealth inequality in the long run
}

(note: this is the authors post-print version of the article appeared in How Was Life? Vol.2. Please cite as: G. Alfani and S. Schifano, "Wealth inequality in the long run", in J.L. Van Zanden et al., eds., How Was Life? Volume II, OECD, 2021, pp. 103-23)

\begin{abstract}
This chapter provides an overview of long-term changes in wealth inequality based on the Gini index and the wealth share of the richest $10 \%^{1}$. The chapter relies on current databases such as the World Inequality Database (WID) but expands the time series for a range of countries (back to 1820 in the case of France, Italy, Sweden, the United Kingdom and the United States) and by producing new estimates.

Our data confirm the general picture of a creeping increase in inequality during the 19th century, followed by declines from the onset of World War I (1914) until the 1960s and, in many (but not all) countries, a new tendency towards higher inequality since the 1970s. The correlation of wealth inequality with per capita GDP is found to be quite weak and not always positive, implying that higher wealth inequality cannot be considered a simple side effect of economic growth.
\end{abstract}

\footnotetext{
${ }^{1}$ The authors wish to thank Peter Lindert, Livio Di Matteo, Salvatore Morelli and Giacomo Gabbuti for supplying us with some data on wealth inequality. This chapter received support from the European Research Council under the European Union's Horizon 2020 Framework Program/ERC Grant agreement No. 725687, SMITE-Social Mobility and Inequality across Italy and Europe, 1300-1800, as well as from the Luxembourg National Research Fund (FNR) (12553347).
} 


\section{Introduction}

In recent years studies on historical developments in economic inequality have flourished. Much of this new research has focused on income inequality during the 19th and 20th centuries, continuing a trend that had been triggered by Simon Kuznets's seminal article (Kuznets, 1955). This greater attention to distribution is surely connected to the tendency towards the increase in income inequality in past decades, as well as to the Great Recession that started in 2007, whose effects are still felt today - among them a much-heightened perception of inequality as a social and political issue. One factor characterising this renewed interest in inequality is that it has not been limited to income, as was almost invariably the case in the past, but has involved wealth, which in recent decades has shown a tendency towards becoming ever more concentrated (Atkinson, 1980; Di Matteo, 2018; Lindert and Williams on, 2016; Piketty, Postel-Vinay and Rosenthal, 2014; Piketty, 2014; Roine and Waldenström, 2015). An even greater attention to wealth inequality has been paid by studies focusing on preindustrial times (as a rule of thumb, pre-1800), which - for a long period - had remained uncharted territory for inequality studies (Alfani, 2015; Alfani, 2017; Alfani and Ammannati, 2017; Alfani and Di Tullio, 2019; Bengtsson et al., 2018; Canbakal, Filiztekin and Pamuk, 2018; Nicolini and Ramos Palencia, 2016). Indeed, for some areas of the world (especially Europe) we now probably know more about wealth inequality in preindustrial times than during the 19th or even most of the 20th century.

Overall, recentfindings about long-run inequality trends, of both income and wealth, have significantly changed how we look not only at historical distributive dynamics, but also at current inequality levels and tendencies. For example, they have led many scholars to explicitly reject Kuznets's hypothesis about the existence of an innate tendency for economic inequality to decline after the achievement of a certain level of development (Lindert, 2000), as well as to question all sorts of mono-causal explanations of changes in inequality (Alfani and Ryckbosch, 2016; Alfani and Di Tullio, 2019; Lindert and Williams on, 2016). In this chapter, some of the insights from these studies will be used to better understand the nature of the inequality trends we describe.

One important reason why tendencies in wealth inequality have become crucial to current studies on distributional dynamics is the awareness that a high concentration of material and financial assets could hinder the way in which modern societies are supposed to function. No one has been more influential in making this point than Thomas Piketty (Piketty, 2014; 2015). In Piketty’s view, as long as the rate of return on capital is higher than the growth rate of national income, and as long as wealth is highly inheritable, inequality (of both income and wealth) will continue to increase. But this might prove 
incompatible with the principles of social justice and equal access to public institutions, which are the basis of contemporary democracies. More generally, there is a growing concern that excessively high wealth inequality may compromise the openness of societies and have negative consequences for longterm social and economic development, for example by making upward mobility more difficult (OECD, 2015).

This chapter presents the available information about wealth inequality in the last two centuries. Unfortunately, for most areas of the world this information continues to be much less systematic than what is available for income inequality. Subsequently, we describe the general trends of wealth inequality, and we provide a brief account of some of the current debates on the drivers of changes in inequality in the long run of history.

\section{Des cription of the concepts used}

The analyses presented in this chapter refer to the distribution of household net wealth. We measure inequality via two standard indicators: the Gini index and the wealth share of the richest $10 \%$. Both choices require further discussion.

At the outset, we have to acknowledge that there is currently no universal consensus about what we should consider when measuring "wealth". Indeed, if we wanted to measure the distribution of all economic resources, we should take into account human capital (Davies and Shorrocks, 2000), or the sum of what are sometimes referred to as "embodied" and "relational" wealth (embodied wealth includes knowledge and skills as well as physical characteristics like strength) (Borgerhoff Mulder et al., 2009). Even if we restricted the analysis to non-human capital, there would still be some doubt about which components of wealth we should include. It might seem straightforward to define wealth as "net worth", i.e. the monetary value of assets (both real property and financial claims) minus the value of liabilities. But this leads to questions about the inclusion of intangible assets that could not easily be sold, for example, pension rights or entitlements to future government transfers. In practice, applied research on wealth usually focuses on net "marketable wealth" (Davies and Shorrocks, 2000, p. 60). A final point to consider is that in the history of economic thought, two different ideas have confronted each other, one considering wealth as a set of tangible possessions (the notion of net wealth is related to this view), the other focusing not on tangibles per se, but on the pleasure or "utility" that they generate (Heilbroner, 2008). A different way of raising not-entirely-dissimilar concerns comes from anthropology, which has suggested that wealth and affluence are not universal concepts, and that the possession of assets has different meanings and consequences in different societies (Sahlins, 1974). 
This being said, the most frequently used concept is that of net (marketable) wealth, which also corresponds to by far the largest part of the currently available information. This is the kind of information provided by the World Inequality Database(WID), for example. Consequently, the data presented here have to be understood as referring to net wealth (although for earlier epochs and for some areas we often have more limited information, hence some adjustments were required). This definition of wealth is also in line with OECD recommendations in this field (OECD, 2013). Note that our measures refer, ideally, to wealth at the household level, without adjustments for household size, again reflecting data availability and common practice. However, for some countries and periods we rely on individual-level distributions (adults) due to the absence of information about household distributions. Based on the available literature - see the discussion in (Roine and Waldenström, 2015, p. 513) - we expect that measures of wealth inequality at the individual level differ only slightly from those calculated at the household level.

Regarding the inequality measures, the Gini index of concentration is an obvious choice, not only because of its vast application in the social sciences, but also because a significant amount of the information we have available is expressed as a Gini value. The index value varies between 0 (perfect equality, i.e. all households or individuals have the same wealth) and 1 (perfect inequality, i.e. one household or individual owns all the wealth, the others have none). However, the Gini index is often multiplied by 100 for more effective presentation, as we do here. Note that this index can in principle be applied in exactly the same way to wealth and to income - hence we refer to Chapter 11 from (van Zanden et al., 2014), dedicated to income inequality, for further discussion of the index's properties. When applied to wealth, the Gini index tends to be higher than when applied to income, due to the empirical tendency for wealth to be more concentrated than income, see (Davies and Shorrocks, 2000, p. 60).

A well-known limitation of the Gini index is that the same value can describe very different distributions. One practical way of solving this problem is to couple the Gini coefficient with percentiles, which can capture changes in important parts of the overall distribution. In this chapter, we do this by including information on the wealth share of the richest part of the population. But there are other important reasons for considering this additional indicator. One is practical: for a significant number of years and countries, we have information only about the share of the richest $10 \%$. Hence, using information about the top of the distribution allows to improve coverage across time and across countries. It has also been argued that the wealth share of the richest should be used because it is easier 
to understand even without specific training - which is clearly a desirable feature, given the socially sensitive nature of many current debates on inequality and the interest in the topic found across ample strata of civil society. This choice is further justified by the fact that there is a clear empirical tendency for changes in the wealth share of the rich to go hand-in-hand with changes in general inequality as measured by the Gini index (in other words, the Gini index increases/declines as the wealth share of the rich increases/declines). This empirical tendency has been confirmed by studies of both contemporary and historical societies (Alfani, 2015; Alfani, 2017; Atkinson, Piketty and Saez, 2011; Alvaredo et al., 2013; Roine and Waldenström, 2015). Finally, it has been argued that in studies of wealth inequality the top shares are to be preferred to the Gini because wealth (unlike income) can assume negative values for indebted households at the bottom of the distribution - indeed, in the presence of negative wealth, the Gini value could theoretically exceed 1 (or 100 in our preferred format) (Balestra and Tonkin, 2018). This, however, does not happen across our database, either because the original sources used do not allow for negative wealth (this would be the case of most property tax records and estate data sources), or because the research teams producing the data we rely upon set the minimum value of net household wealth at zero. This is the case for the World Inequality Database (Alvaredo, F.; A. Atkinson and L. Chancel, 2016), in particular Annex Table A1, which is the main source of the estimates included in this chapter. This consideration enhances the case for coupling the Gini index with top shares or other indicators with similar properties.

The existence of a strong empirical correlation between the share of the richest and the Gini index presents the additional advantage of offering a simple and relatively reliable way of estimating one from the other when complete information is unavailable - which unfortunately is very often the case, as discussed in the next section. We made use of this procedure, with some adaptation, as the preferred way to complete gaps in the database of Gini indices or of the share of the top $10 \% .^{2}$ This method is preferable to other options, like interpolation, because it makes use of at least some information about the actual distribution in a given country and year, although we had to resort to interpolation when neither the Gini nor the share of the top $10 \%$ were available. The estimated relationship between the Gini and the share of the richest $10 \%$ is the following. ${ }^{3}$

$$
\text { Gini }=0.30+0.72 * \text { Top } 10
$$

\footnotetext{
2 Note that across our database, the Pearson coefficient between the Gini index and the share of the richest $10 \%$ is 0.94 , suggesting a very strong correlation. The Pearson coefficient has been calculated on the 258 country-years for which both Gini and the share of the top $10 \%$ were available.
}

${ }^{3}$ With an $\mathrm{R}^{2}$ of 0.8756 , an adjusted $\mathrm{R}^{2}$ - of 0.8751 and a t-statistics of 42.61 . 
The main objective of this chapter is to provide a long-term perspective on wealth inequality in individual countries. However, we also provide some hints about the global distribution of household wealth (i.e. that obtained by considering all the households in the world as living in the same country). This task is performed with a method analogous to that employed in Chapter 11 of (van Zanden et al., 2014), which provides additional details. Applying this method requires some assumptions. In particular, we rely upon available estimates of the average net wealth at the country level, and assume log-normality to estimate wealth distributions starting from the Gini coefficient and the net private wealth for each country and year. Global wealth distributions are then obtained by aggregating country level distributions for each year. Unfortunately, we could produce global estimates only for the more recent years, given the sparse nature of the available information about wealth inequality (even including new estimates and "guess-estimates"), as detailed in the next section. We do however provide estimates of overall wealth inequality since 1850 across a small group of Western countries (France, Sweden, the United Kingdom and the United States).

\section{Historical sources}

The information currently available about the distribution of wealth is much sparser than that relating to income. In order to build as comprehensive a database as possible, we needed to rely upon disparate sources as well as to produce some new estimates.

Most of the available historical evidence about wealth concentration comes from wealth and estate taxation statistics. Tax sources also allow building the longest time series (Roine and Waldenström, 2015). However, they also have a number of limitations. A particularly important one is that often they include only the richest part of the population, which is why many applied studies have relied upon the wealth share of the richest to summarise inequality levels and trends. But this coverage problem does not always occur. For example, the Italian estimi (property tax records used until the turn of the 19th century) included at least 90-95\% of the overall population (Alfani, 2015; Alfani and Di Tullio, 2019). Similar sources exist for other parts of Europe (for example southern France, north-eastern Spain and parts of Germany). Unfortunately, this kind of information is not widely available for later periods due to changes in the fiscal systems. In this chapter, these sources have been used only to estimate wealth inequality in Italy in the first part of the 19th century.

A general concern with all fiscal sources is the level of tax evasion and avoidance. Although it is usually very difficult to quantify this, it should be noted that at least some components of wealth - like 
real estate - are relatively difficult to hide, or to misevaluate dramatically. This being said, the opportunity for wealth tax evasion and avoidance probably tended to increase during the two centuries covered by this chapter, for example because in the current global economy it has become easier to hide movable wealth by means of tax havens or otherwise (Roine and Waldenström, 2015).

Alternative sources feeding the data used in this chapter include estate data (which usually do not cover the entire population, but result from researchers' attempts at building representative samples) as well as probate inventories (data from the judicial process through which a will is accepted as the legal testament of the deceased). The latter are relatively popular in historical research, due to the vast archival availability of probates since early epochs. A useful feature of probates is that they exist for non-European areas, too, like the Ottoman lands in Anatolia and the Levant (Coşgel and Ergene, 2012; Canbakal, Filiztekin and Pamuk, 2018). However, due to the vast amount of archival research needed to produce national samples of probates, so far it has been possible to produce comprehensive and reliable wealth distributions based on them only for a few countries and years. Moreover, and most importantly, they do present specific challenges related to sampling - as, again, they often reflect the richest part of the population far better than the poorest, and require assumptions about mortality rates by age, sex and socio-economic status to move from the distribution of wealth of those dying in a given period to the hypothetical distributions characterising living cohorts in earlier periods (Bengtsson et al., 2018; Lindert, 1986; Roine and Waldenström, 2015).

The main databases we drew information from provide us with standardised measures that usually incorporate attempts at correcting the limitations in the original sources described above. In particular, we relied heavily upon the World Inequality Database (WID) (WID.world), from which comes most of the information we have for the period 1900-2000 (recent releases of the database have greatly increased the coverage of wealth inequality, although much more information is available about income). For 2010, we have also collected information from the Global Wealth Databooks(GWD), published by Credit Suisse's Research Institute (Credit Suisse). The Databooks include estimates for a number of countries ranging from 20 to 30 according to the year, based on a combination of national accounts and household survey data supplemented by a variety of estimation methods. For this year and for a large subset of OECD countries, high-quality data from the OECD Wealth Distribution Database (WDD) (OECD), based on a combination of household surveys and (for some countries) administrative data, are also available. We preferred relying upon the GWD for later years due to the much larger number of countries covered as well the higher (albeit far from perfect) consistency with the estimation methods used by the WID. However, we also used the WDD as a means of external validation of our findings. For earlier periods, we relied upon a greater variety of sources, reflecting 
the specificities of the archival and statistical information produced locally as well as the degree of advancement of historical research on inequality and related topics.

Only for very few countries covered by this chapter is information about wealth inequality available as far back as 1820. Especially for Africa and Asia, the estimates tend to begin only in the second half of the 20th century (the earliest estimate we have for these areas refers to Japan in 1870). Estimates extending back to 1820 are available only for five countries in Western Europe and the Western Offshoots: France, the United Kingdom, Italy, Sweden and the United States. The sources and information used in this chapter for these five countries are detailed below.

France is the country whose wealth distribution during the 19th century has been researched most thoroughly. This is due especially to the research conducted by (Piketty, Postel-Vinay and Rosenthal, 2006; Piketty, Postel-Vinay and Rosenthal, 2014; Piketty, 2014). Indeed, of all the countries covered by this chapter, France is the only one for which complete series of wealth Gini indices and top shares are readily available, without the need for additional estimates, for the entire period 1820-2010. We used the standardised series recently made available by the WID.

For the United Kingdom, we made use of estimates of the share of the richest $10 \%$ produced by (Lindert, 1986) for selected years during the late 18th and the 19th century, with some additional estimates used to fill in the gaps. Lindert's estimates are based on data from probates, coupled with various other sources to account properly for some specific components of wealth, like real estate. From 1900, the WID provides fairly systematic data about the wealth share of the richest $10 \%$. Information about UK Gini index is much scarcer, and it is only from the 1970s that a series of Gini indices is available, from (Alvaredo, Atkinson and Morelli, 2018). This led us to produce a large number of new estimates by means of the correlation procedure described in the earlier section.

For Italy, wealth inequality measures for 1820 have been produced using information from studies of long-term inequality trends in preindustrial times (based on fiscal sources and particularly on property tax records) in a variety of Italian pre-unification states - for example (Alfani, 2015; Alfani, 2017; Alfani and Di Tullio, 2019; Alfani and Ryckbosch, 2016). Information for later periods is scattered (Schneider, Pottenger and King, 2016; Brandolini et al., 2004; Davies et al., 2010; Credit Suisse, 2017; Gabbuti and Morelli, 2019); as the WID, does not provide this information for Italy, hence many new and rather tentative estimates have been produced. 
For Sweden during the 19th century, Bengtsson et al. (2018) produced estimates of both the Gini index and the wealth share of the richest $10 \%$ for selected years by using data from probate inventories. For the 20th century, the same was done by Roine and Waldenström (2015) regarding the share of the richest 10\%, while Schneider, Pottenger and King (2016) provided Gini estimates for 2000. Also, in this case, many additional estimates were required to fill in the gaps.

Finally, for the United States, very tentative estimates of top wealth shares during the 19th century have been produced by interpolation between an observation for 1774 based on data provided by Lindert (2000), one for 1870 provided by Sutch (2016) and one for 1890 by Roine and Waldenström (2015); Schneider, Pottenger and King (2016) provide a Gini index for 1870. For the 20th and early 21st centuries, the data we use for the share of the richest $10 \%$ and for the Gini indices mostly come from the WID. New tentative estimates have been produced to fill in the gaps.

Table 5.1 and Table 5.2 provide an overview of the kind of information used in this chapter, specifying the original data source and the estimation method used. As far as the share of the top $10 \%$ is concerned, the WID provided $21 \%$ of the data used in our analysis, while the publicly available database by Roine and Waldenström (2015) furnished another 13\% of the data. Regarding the Gini indexes, 33\% of the observations are new estimates obtained by correlation with the share of the top 10\% (as discussed earlier). The WID and Schneider, Pottenger and King (2016) together supplied 18\% of the other data.

For both the Gini indices and the share of the top 10\%, 34\% of observations had to be produced by simple interpolation, although sometimes between very close dates (for example, the estimate for Italy in 1990 is obtained by interpolating the observations for 1989 and 1991).

Unfortunately, as is quite clear, good-quality estimates of wealth inequality are only sparsely available, hence to provide at least an impression of long-term trends we had to rely heavily on new and often very tentative estimates. Also note that for some areas and periods more than one estimate is available, hence we had to make informed decisions about which one to rely upon. Beyond the general guidelines described in this section, we aimed to ensure consistency in the reconstructed series, to avoid reporting clearly artificial trends, and to offer a picture that is overall consistent with the most recent literature on single countries or areas. 
Table 5.1. Es timates of wealth ine quality used in this chapter by source and benchmarked year, 1820-2010, Gini coefficients

Number of countries covered

\begin{tabular}{|c|c|c|c|c|c|c|}
\hline & All & $\begin{array}{c}\text { World } \\
\text { Inequality } \\
\text { Database }\end{array}$ & $\begin{array}{c}\text { Schneider, } \\
\text { Pottenger } \\
\text { and King } \\
\text { (2016) }\end{array}$ & $\begin{array}{l}\text { New } \\
\text { estimate } \\
\text { (obtained by } \\
\text { correlation } \\
\text { with share of } \\
\text { top 10\%) }\end{array}$ & $\begin{array}{c}\text { New } \\
\text { estimate } \\
\text { (obtained by } \\
\text { interpolation) }\end{array}$ & $\begin{array}{l}\text { Other } \\
\text { sources }\end{array}$ \\
\hline 1820 & 5 & 1 & & 1 & 3 & \\
\hline 1830 & 5 & 1 & & & 4 & \\
\hline 1840 & 5 & 1 & & & 4 & \\
\hline 1850 & 5 & 1 & & & 3 & 1 \\
\hline 1860 & 5 & 1 & & & 4 & \\
\hline 1870 & 6 & 1 & 1 & 1 & 2 & \\
\hline 1880 & 6 & 1 & & & 5 & 1 \\
\hline 1890 & 7 & 1 & 1 & 2 & 3 & \\
\hline 1900 & 7 & 1 & 1 & 2 & 2 & 1 \\
\hline 1910 & 11 & 1 & 1 & 3 & 5 & 1 \\
\hline 1920 & 12 & 1 & & 5 & 6 & \\
\hline 1930 & 12 & 1 & & 5 & 6 & \\
\hline 1940 & 12 & 1 & & 4 & 7 & \\
\hline 1950 & 12 & 1 & & 7 & 4 & \\
\hline 1960 & 13 & 2 & & 6 & 5 & \\
\hline 1970 & 17 & 2 & 1 & 6 & 3 & 5 \\
\hline 1980 & 18 & 3 & & 4 & 6 & 5 \\
\hline 1990 & 21 & 4 & 1 & 4 & 5 & 7 \\
\hline 2000 & 25 & 4 & 3 & 3 & 2 & 13 \\
\hline 2010 & 36 & 4 & 1 & 27 & 2 & 2 \\
\hline Total & 240 & 33 & 10 & 80 & 81 & 36 \\
\hline
\end{tabular}


Table 5.2. Estimates of the wealth share of the richest $10 \%$ used in this chapter by source and benchmark year, 1820-2010

Number of countries covered

\begin{tabular}{|c|c|c|c|c|c|c|c|}
\hline & All & $\begin{array}{c}\text { World } \\
\text { Inequality } \\
\text { Database }\end{array}$ & $\begin{array}{c}\text { Credit } \\
\text { Suisse } \\
\text { Global } \\
\text { Wealth } \\
\text { Databooks }\end{array}$ & $\begin{array}{c}\text { New } \\
\text { estimate } \\
\text { (obtained } \\
\text { by } \\
\text { correlation } \\
\text { with Gini } \\
\text { coefficient) }\end{array}$ & $\begin{array}{c}\text { New } \\
\text { estimate } \\
\text { (obtained by } \\
\text { interpolation) }\end{array}$ & $\begin{array}{c}\text { Roine and } \\
\text { Waldenström } \\
\text { (2015) }\end{array}$ & $\begin{array}{l}\text { Other } \\
\text { literature }\end{array}$ \\
\hline 1820 & 5 & 1 & & & 3 & & 1 \\
\hline 1830 & 5 & 1 & & & 4 & & \\
\hline 1840 & 5 & 1 & & & 4 & & \\
\hline 1850 & 5 & 1 & & & 3 & & 1 \\
\hline 1860 & 5 & 1 & & & 4 & & \\
\hline 1870 & 6 & 1 & & & 2 & & 2 \\
\hline 1880 & 6 & 1 & & 1 & 5 & & \\
\hline 1890 & 7 & 1 & & & 3 & 1 & 2 \\
\hline 1900 & 7 & 2 & & & 2 & & 3 \\
\hline 1910 & 11 & 3 & & 1 & 5 & & 2 \\
\hline 1920 & 12 & 3 & & & 6 & 3 & \\
\hline 1930 & 12 & 3 & & & 6 & 3 & \\
\hline 1940 & 12 & 3 & & & 7 & 1 & 1 \\
\hline 1950 & 12 & 3 & & & 4 & 3 & 2 \\
\hline 1960 & 13 & 3 & & & 5 & 3 & 2 \\
\hline 1970 & 17 & 3 & & 4 & 3 & 4 & 3 \\
\hline 1980 & 18 & 4 & & 2 & 6 & 2 & 4 \\
\hline 1990 & 21 & 5 & & 5 & 5 & 4 & 2 \\
\hline 2000 & 25 & 5 & & 5 & 2 & 4 & 9 \\
\hline 2010 & 36 & 5 & 23 & & 2 & 2 & 4 \\
\hline Total & 240 & 50 & 23 & 18 & 81 & 30 & 38 \\
\hline
\end{tabular}




\section{Data quality}

In Table 5.3 and Table 5.4 we provide an assessment of the quality of the data used in this chapter. So far, the study of wealth inequality has not produced a unique database containing comparable data in terms of both unit of analysis and methodologies used to gather them. Studies of wealth inequality in the past have relied upon national sources that provide different information about wealth distributions. Most of them are based on wealth tax statistics, estate records, probates, and for the last decades, household surveys. Moreover, given the presence of numerous gaps between the readily available measures, we had to produce many new estimates. This is why, according to the parameters defined in Chapter 1 of (van Zanden et al., 2014), in most instances data quality has to be classified as "low" or "moderate". Note that the situation is better regarding measures of the share of the richest $10 \%$ compared to Gini indexes. To a large degree this is due to the World Inequality Database(WID), which is the most comprehensive database in this field of enquiry. For many countries and years, the WID provides us with good estimates of the wealth share of the richest percentiles. Other sources have been used for specific countries, as detailed previously, as well as for the 19th century, which is not usually covered by the WID (France is the notable exception).

Collecting estimates of the Gini coefficients for the period under study was more difficult. Indeed, earlier research has focused mostly on the top percentiles, also because it is much easier to gather data on the right-hand side of the wealth distribution. However, there is strong empirical evidence that the wealth share of the richest $10 \%$ and the Gini index are strongly correlated. Indeed, for the sub-set of countries and years for which we had information about both, the Pearson correlation coefficient is 0.94. This allowed us to present estimates of the Gini coefficient starting from values of the top 10\% whenever we lacked a direct measure of the former. Less often we predicted the top share from the Gini coefficient. This is a simple estimation method which, in the absence of any useful additional information, seems preferable to more complex procedures. A more detailed description of our methods is provided in the section "Description of the Concepts Used". Furthermore, we have systematically assigned a lower data quality to predicted measures than to original measures. 
Table 5.3. Quality of estimates of the Gini coefficient of wealth ine quality by region and benchmark year, 1820-2010

\begin{tabular}{c|c|c|c|c|c|c|c|c}
\hline & $\begin{array}{c}\text { Western } \\
\text { Europe }\end{array}$ & $\begin{array}{c}\text { Eastern } \\
\text { Europe }\end{array}$ & $\begin{array}{c}\text { Western } \\
\text { Offshoots }\end{array}$ & $\begin{array}{c}\text { Latin } \\
\text { America } \\
\text { and } \\
\text { Caribbean }\end{array}$ & $\begin{array}{c}\text { Middle } \\
\text { East and } \\
\text { North } \\
\text { Africa }\end{array}$ & $\begin{array}{c}\text { Sub- } \\
\text { Saharan } \\
\text { Africa }\end{array}$ & $\begin{array}{c}\text { East } \\
\text { Asia }\end{array}$ & $\begin{array}{c}\text { South } \\
\text { and } \\
\text { Southeast } \\
\text { Asia }\end{array}$ \\
\hline 1820 & 3 & & 4 & & & & & \\
\hline 1870 & 3 & & 4 & & 3 & & & \\
\hline 1910 & 3 & & 4 & & & & 4 & \\
\hline 1960 & 3 & & 4 & & & & 3 & 2 \\
\hline 1990 & 3 & 4 & 2 & 3 & & & 3 & 3 \\
\hline 2010 & 3 & 3 & 2 & 3 & 2 & 4 & 3 \\
\hline
\end{tabular}

Note: 1: High quality; 2: Moderate quality; 3: Low quality; 4: Tentative estimates. The table reports rounded mean values per world region/benchmarked year.

Table 5.4. Quality of estimates of the wealth share of the reachest $10 \%$ of the population by region and be nchmark ye ar, 1820-2010

\begin{tabular}{l|c|l|l|c|c|c|c|c}
\hline & $\begin{array}{c}\text { Western } \\
\text { Europe }\end{array}$ & $\begin{array}{c}\text { Eastern } \\
\text { Europe }\end{array}$ & $\begin{array}{c}\text { Western } \\
\text { Offshoots }\end{array}$ & $\begin{array}{c}\text { Latin } \\
\text { America } \\
\text { and } \\
\text { Caribbean }\end{array}$ & $\begin{array}{c}\text { Middle } \\
\text { East and } \\
\text { North } \\
\text { Africa }\end{array}$ & $\begin{array}{c}\text { Sub- } \\
\text { Saharan } \\
\text { Africa }\end{array}$ & $\begin{array}{c}\text { East } \\
\text { Asia }\end{array}$ & $\begin{array}{c}\text { South } \\
\text { and } \\
\text { Southeast } \\
\text { Asia }\end{array}$ \\
\hline 1820 & 3 & & 4 & & & & & \\
\hline 1870 & 3 & & 4 & & 3 & & & \\
\hline 1910 & 3 & & 4 & & & & 4 & \\
\hline 1960 & 2 & & 4 & & & & 4 & \\
\hline 1990 & 2 & 4 & 2 & 3 & & & 3 & 2 \\
\hline 2010 & 2 & 3 & 2 & 3 & 2 & 4 & 3 & 3 \\
\hline
\end{tabular}

Note: 1: High quality; 2: Moderate quality; 3: Low quality; 4: Tentative estimates. The table reports rounded mean values per world region/benchmarked year. 


\section{Main highlights of historical trends in we alth ine quality}

This section provides an overview of long-term tendencies in wealth inequality, focusing on developments within countries and underlying commonalities and differences across world regions. It also provides a tentative picture of global wealth inequality, generally restricted to the most recent periods given the limited availability of information about wealth distribution in many areas of the world until the final decades of the 20th century.

\section{Developments in individual countries}

At 1820, we have information about wealth inequality for only five of the countries included in Table 5.5 and Table 5.6, and all of them are in the West: France, the United Kingdom, Italy and Sweden in Western Europe, plus the United States in the Western Offshoots. In this year, Gini indices range from 88 to 90 in Europe, while the United States was significantly more "egalitarian" with a Gini of 76. The wealth share of the richest $10 \%$ marks an even greater distance, being in the 81-85\% range in Europe, and $62 \%$ in the United States. This difference in wealth inequality between Western European countries and the United States in the 19th century is well documented in historical research (Lindert and Williams on, 2016). The gap between Europe and the United States tended to narrow during the 19th century, without disappearing entirely. By 1900, with a Gini of 84, the United States was still slightly more egalitarian than any European country with available data, although only marginally so compared to Italy where the Gini was 83. For that year, we also have information about Canada which, with a Gini of 89, was basically in line with European countries. The only non-Western country for which we have data in 1900, Japan, is significantly more egalitarian, with a Gini coefficient of 53 and a wealth share of the richest $10 \%$ of $36 \%$, well below the $75-93 \%$ range characterising Western Europe and the Western Offshoots as a whole.

Importantly, during the 19th century we find an overall tendency for wealth inequality to increase. This is clearer in the United Kingdom, Sweden and the United States compared to France and Italy, whose trends are quite flat. This finding could be taken to fit the narrative of the "Kuznets curve" which, although originally related to income, can reasonably be applied to wealth as well, see pp. 215219 in Lindert (1991) - with growing inequality seen as the consequence of the Industrial Revolution. However, recent research focused on longer time periods casts doubt on this, as this phase of increasing inequality seems to be the continuation of a multi-secular phase of wealth inequality growth that started around the 15th century, that is, after a phase of declining inequality (of both wealth and income) 
triggered by the Black Death plague of 1347-1352 (Alfani, 2017; Alfani, 2019; Alfani and Di Tullio, 2019; Alfani and Ryckbosch, 2016).

Wealth inequality continued to grow during the first decade of the 20th century. In Western Europe and its Offshoots, this tendency was halted by World Wars I and II and by the troubled times in between. The multi-faceted impact of war and large-scale societal and economic disruption has been variously presented as the direct cause of the inequality decline characterising the period from 1914 to 1945 (Piketty, 2014; Scheidel, 2017). Indeed, in each country for which we have information about wealth inequality in both 1910 and 1950, we find a decline over the period. For example in Australia, whose first available observation dates to 1910, the Gini coefficient declines sharply, from 86 to 63, and the share of the richest $10 \%$ falls from $75 \%$ to $64 \%$. The tendency for a decline in wealth inequality continued for about two decades after 1950, probably (at least in advanced countries) also as a consequence of fiscal redistribution and the associated development of the welfare state: think about, for example, the spread of public programmes supporting home ownership (Atkinson, Piketty and Saez, 2011; Alvaredo et al., 2013; Piketty, 2014). From the late 1970s - the beginning of a phase of fiscal reform leading to lower progressiveness in income taxation and lower inheritance taxes, as well as of deregulation in the financial sector (Alfani, 2019; Piketty, 2015) - we find in most countries signs of a resumption in the tendency for wealth inequality to grow, which continues to this day. At least to some degree, this could also be related to demographic tendencies in the West. Particularly relevant are increases in life expectancy: as wealth is positively correlated with age, due to higher cumulated savings, an aging population tends to be characterised by a more dispersed, hence more unequal, wealth distribution - for a discussion of this general problem, which is also relevant for income, see Paglin (1975). According to some studies, population aging is a contributing factor of wealth inequality growth, for example in Germany (Ihle and Siebert-Meyerhoff, 2017), although this effect can be expected to wane and finally disappear as Western populations grow even older.

From 1970 onwards, we can compare inequality levels between more world areas. At that date, the Gini index in Western Europe ranged from 65 to 77; in the Western Offshoots from 52 to 84 (72-84 if we restrict the observation to North America); in Latin America and the Caribbean from 61 to 86; and in Asia, 52, where the only estimate available refers to Japan. However for China in 1980 our estimate of the Gini index is 54, suggesting that overall East Asia was relatively egalitarian (differences in political regimes between China and Japan do not seem to be associated with significantly different inequality levels). 
The coverage of our database improves further in subsequent decades. In 2000, the range of Gini levels was 57-89 in Western Europe; 75 in the Russian Federation, which is the only Eastern European country for which we have information; 62-83 in North America and Australia (the latter being, again, the most egalitarian of the group); 74-78 in Latin America and the Caribbean; 72 in Turkey; 55-59 in East Asia (Japan and China respectively); and 67-76 in South and Southeast Asia.

By 2010, the United States stands out as the least egalitarian country among those included in Table 5.5 and Table 5.6 , with a Gini coefficient of 88 and a wealth share of the richest $10 \%$ of $73 \%$. An interesting feature of American history is that, starting from being the most egalitarian of Western societies in the 19th century, it has become exceptionally unequal. This change mainly reflected developments in the interwar period and in the 20-30 years following World War II, when the United States were characterised by a lower decline in inequality than that found in many European countries or Canada. It is also interesting to compare the case of the United States to that of France, which followed much the opposite path, turning from being one of the most unequal Western European countries in the first half of the 19th century to being one of the most egalitarian Western countries today - or at least, one where the inequality increase during the last 40 or 50 years has been exceptionally modest (by 2010, with a Gini of 70, France was as unequal as in 1970. The share of the richest $10 \%$ even declined marginally, from $58 \%$ to $56 \%$ ). 
Table 5.5. Gini coefficient of wealth ine quality in selected countries, 1820-2010

\begin{tabular}{|c|c|c|c|c|c|c|c|c|c|c|c|c|c|c|c|c|c|c|c|c|c|c|c|c|c|}
\hline & \multicolumn{7}{|c|}{ Western Europe } & \multicolumn{2}{|c|}{$\begin{array}{c}\text { Easter } \\
n \\
\text { Europe }\end{array}$} & \multicolumn{3}{|c|}{$\begin{array}{c}\text { Western } \\
\text { Offshoots }\end{array}$} & \multicolumn{3}{|c|}{$\begin{array}{c}\text { Latin } \\
\text { America } \\
\text { and } \\
\text { Caribbean }\end{array}$} & \multicolumn{2}{|c|}{$\begin{array}{l}\text { Middle } \\
\text { East } \\
\text { and } \\
\text { North } \\
\text { Africa }\end{array}$} & \multicolumn{3}{|c|}{$\begin{array}{c}\text { Sub- } \\
\text { Saharan } \\
\text { Africa }\end{array}$} & \multicolumn{2}{|c|}{$\begin{array}{l}\text { East } \\
\text { Asia }\end{array}$} & \multicolumn{3}{|c|}{$\begin{array}{l}\text { South and } \\
\text { Southeast } \\
\text { Asia }\end{array}$} \\
\hline & GB & NL & FR & $\mathrm{DE}$ & ITA & ES & SW & PO & RU & $\mathrm{AU}$ & CA & US & $\mathrm{ME}$ & $\mathrm{BR}$ & AR & EG & TU & $\mathrm{KE}$ & NG & $\mathrm{ZA}$ & $\mathrm{CH}$. & JPN & IN & ID & $\mathrm{TH}$ \\
\hline & $\mathrm{R}$ & D & A & $\mathrm{U}$ & & $\mathrm{P}$ & $\mathrm{E}$ & $\mathrm{L}$ & $\mathrm{S}$ & $S$ & $\mathrm{~N}$ & A & $\mathrm{X}$ & A & $\mathrm{G}$ & $\mathrm{Y}$ & $\mathrm{R}$ & $\mathrm{N}$ & A & $\mathrm{F}$ & $\mathrm{N}$ & & $\mathrm{D}$ & $\mathrm{N}$ & A \\
\hline 1820 & [90] & & 88 & & 89 & & [90] & & & & & [76] & & & & & & & & & & & & & \\
\hline 1830 & [90] & & 87 & & [88] & & [89] & & & & & [78] & & & & & & & & & & & & & \\
\hline 1840 & [90] & & 86 & & [88] & & [88] & & & & & [79] & & & & & & & & & & & & & \\
\hline 1850 & [90] & & 90 & & [87] & & 87 & & & & & {$[80]$} & & & & & & & & & & & & & \\
\hline 1860 & [90] & & 88 & & [87] & & [90] & & & & & [82] & & & & & & & & & & & & & \\
\hline 1870 & 90 & & 87 & & [86] & & [93] & & & & & 83 & & & & & & & & & & 53 & & & \\
\hline 1880 & [92] & & 87 & & [86] & & [92] & & & & & [83] & & & & & & & & & & [53] & & & \\
\hline 1890 & [94] & & 88 & & 86 & & [92] & & & & 91 & [82] & & & & & & & & & & [53] & & & \\
\hline 1900 & 97 & & 89 & & 83 & & 91 & & & & 89 & [84] & & & & & & & & & & [53] & & & \\
\hline 1910 & 96 & & 89 & & 81 & & [94] & & & 86 & [87] & [87] & & & & & & & & & & [53] & & & \\
\hline 1920 & 94 & & 88 & & [79] & & [96] & & & [80] & [84] & [86] & & & & & & & & & & [52] & & & \\
\hline 1930 & 92 & & 87 & & [77] & & [95] & & & [74] & [82] & [91] & & & & & & & & & & [52] & & & \\
\hline 1940 & 91 & & 82 & & [74] & & [90] & & & [69] & [79] & [86] & & & & & & & & & & [52] & & & \\
\hline 1950 & 88 & & 82 & & [71] & & {$[86]$} & & & [63] & 77 & [79] & & & & & & & & & & [52] & & & \\
\hline 1960 & 81 & & 80 & & [68] & & [79] & & & 58 & 70 & 84 & & & & & & & & & & [52] & & & \\
\hline 1970 & 77 & & 70 & 75 & [65] & & [72] & & & 52 & 72 & 84 & 61 & 84 & 86 & & & & & & & [52] & & & \\
\hline 1980 & 65 & & 66 & 70 & [62] & & 69 & & & 66 & 69 & 81 & [66] & 85 & 84 & & & & & & 54 & 52 & & & \\
\hline 1990 & 64 & 78 & 65 & 62 & 58 & & 72 & & 67 & 64 & 69 & 79 & [70] & 85 & 83 & & & & & & 54 & 56 & 66 & & \\
\hline 2000 & 71 & 79 & 70 & 67 & 61 & 57 & 89 & & 75 & 62 & 69 & 83 & 75 & 78 & 74 & & 72 & & & & 59 & 55 & 67 & 76 & 71 \\
\hline 2010 & 69 & 81 & 70 & 73 & 63 & 67 & 73 & 58 & 78 & 61 & 71 & 88 & & 82 & & & & & & 82 & 73 & 65 & 80 & 78 & 78 \\
\hline
\end{tabular}

Note: For an assessment of data quality, see Table 5.3 and Table 5.4. The complete database, including information about the sources used for each country/year, can be downloaded from http://didattica.unibocconi.eu/Alfani_database.

Values in brackets [ ] indicate very tentative data.

StatLink 2 https://stat.link/swhjlm 
Table 5.6. Wealth share of the richest $10 \%$ of the population in selected countries, 1820-2010

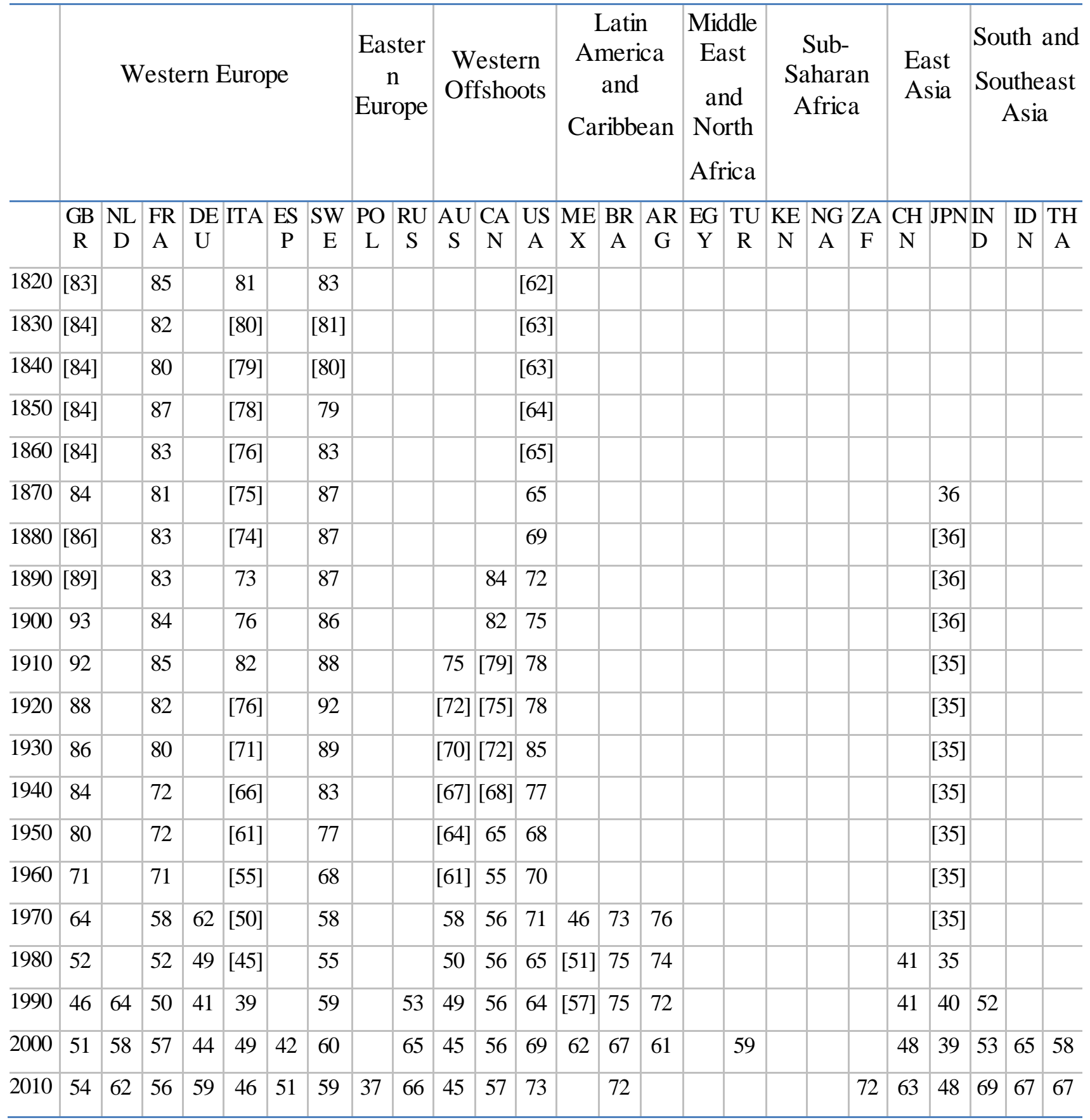

Note: For an assessment of data quality, see Table 5.3 and Table 5.4. The complete database, including information about the sources used for each country/year, can be downloaded from: http://didattica.unibocconi.eu/Alfani_database.

Values in brackets [ ] indicate very tentative data.

StatLink 2 https://stat.link/8okbt9 


\section{Regional comparisons}

The country-level data reported above allow for some regional comparisons, as shown in Table 5.7 (for all world regions except sub-Saharan Africa and the Middle East and North Africa). The measures shown in the table do not reflect differences in net wealth between countries nor country population sizes, but are simple averages of Gini coefficients. Table 5.7, which we restricted to 1950-2010 to avoid presenting measures based on few country observations, shows the final phase of decline in within-country wealth inequality in Western Europe and in the Western Offshoots, from the 1950s to the 1970s. This decline, which is usually associated with the development of the welfare state (see discussion above), has been followed in the last 40-50 years by stagnation and then an upward creep (which was more clearly visible in the country-level data presented in Table 5.5 and Table 5.6).

A period of declining inequality seems to have been followed by one of rising inequality also in East Asia, where average inequality today is very close to that of Western Europe. East Asia and Western Europe are the only two world regions that, in 2010, were below the world average of 72. The Gini index for the Latin America and Caribbean region matches the average perfectly, while that for the Western Offshoots (at 74) is just above it. South and Southeast Asia leads the ranking, with a Gini index of 82 (although excluding Singapore drops this to 79). This picture does not change much if we look at 2000 (when database coverage is highest) instead of 2010, with the exception of the Latin America and Caribbean region, which jumps to the top of the ranking. The very high wealth inequality in the Latin America and Caribbean area in 2000 mirrors its exceptionally high income inequality (Milanovic, 2005; Prados de la Escosura, 2007).

Table 5.7. We alth inequality across world regions, 1950-2010

Gini coefficients, unweighted averages

\begin{tabular}{l|c|c|c|c|c|c}
\hline & $\begin{array}{c}\text { Western } \\
\text { Europe }\end{array}$ & $\begin{array}{c}\text { Western } \\
\text { Offshoots }\end{array}$ & $\begin{array}{c}\text { Latin } \\
\text { America and } \\
\text { Caribbean }\end{array}$ & East Asia & $\begin{array}{c}\text { South and } \\
\text { Southeast } \\
\text { Asia }\end{array}$ & World \\
\hline 1950 & 84 & 73 & & 52 & & 79 \\
\hline 1960 & 80 & 70 & & 52 & & 75 \\
\hline 1970 & 76 & 69 & 77 & 52 & & 71 \\
\hline 1980 & 72 & 72 & 78 & 53 & & 70 \\
\hline 1990 & 70 & 71 & 79 & 55 & 66 & 74 \\
\hline
\end{tabular}




\begin{tabular}{l|l|l|l|l|l|l}
\hline 2000 & 72 & 71 & 76 & 57 & 71 & 71 \\
\hline 2010 & 71 & 74 & 72 & 69 & 82 & 72 \\
\hline
\end{tabular}

Note: For an assessment of data quality, see Table 5.3 and Table 5.4. This table includes all the countries for which we have information about wealth inequality, so this covers a larger group compared to Table 5.5 (hence some slight differences in the value of "World" averages between this table and Table 5.8).

StatLink 2 https://stat.link/p6f9m7

\section{A first glance at the global wealth distribution}

We can provide a global perspective on wealth distribution, by observing the inequality levels corresponding to all the world's households taken together, i.e. as if the whole world were considered as a single country, similarly to what is done for income inequality in Chapter 11 of van Zanden et al. (2014). ${ }^{4}$ Unfortunately, this is not easy to achieve for wealth, given that we do not have complete information for any year, either about inequality levels or about per capita net wealth per country. Consequently, we focus on 2000, which is the year with the largest country coverage. Some additional assumptions were made to obtain estimates of the global wealth distribution in 2000; in particular, we use the information about inequality for South Africa in 2010 to represent the whole of sub-Saharan Africa in 2000, which clearly does not reflect perfectly the overall situation of the area.

Our estimate of the global wealth distribution in 2000 is shown in Figure 5.1, panel A. As can be seen, this global distribution is log-normal (i.e. it assumes a normal shape when the $\mathrm{x}$ axis is expressed in a logarithmic scale), with the mode placed at a per capita net wealth of about USD 8700 (measured as US dollars PPP 2017). The corresponding Gini level is 82, and the share of the richest $10 \%$ is $73 \%$. Our estimate is quite a bit lower than the Gini of 93 (with a share of the top 10\% of $89 \%$ ) estimated for the same year by Davies, Lluberas and Shorrocks (2017) (see in particular pp. 754-5), due to differences in the countries covered and in the methods used. In particular, while we apply to wealth the method used for income in Chapter 11 of van Zanden et al (2014) in order to maximise the internal comparability of measures, Davies and Shorrocks (2000) follow a different approach that adjusts the right tail of the distribution based on the "rich lists" published by Forbes and others.

\footnotetext{
${ }^{4}$ Also see the section "Description of the Concepts Used" about methods.
} 
Unlike what was shown for the income distribution in van Zanden et al (2014), our wealth distribution for 2000 is unimodal. As the coverage of our database is quite imperfect, we cannot identify any time trend. Although in Table 5.8 we include measures of "Global Inequality" for the period 1960-2010, changes in the Gini index are also affected by changes in the country coverage of our database.

For the period 1870-1950, however, we have information about both the Gini index and average net wealth for four Western countries (France, Sweden, the United Kingdom and the United States). If we restrict the analysis to this group, we can indeed detect a time trend for 1870-2010. Figure 5.1, panel $\mathrm{B}$, shows that, in all years, the shape of the distribution is log-normal. The mode of the distribution shifts to the right through time (with the sole exception of the troubled period between 1910 and 1930), reflecting increases in average net wealth, as well as a general spreading out of wealth across the overall population of these countries. This is reflected by an estimated Gini index that declines from 88 in 1870, to 82 in 1950, and 76 in $1990 .{ }^{5}$ Lower wealth inequality in the second half of the 20th century goes hand in hand with convergence in net wealth across the four countries (see below). However, the tendency towards lower wealth inequality within this group of rich Western countries comes to a halt and reverses in the last thirty years or so: after the minimum reached around 1990, the Gini index increases to 80 by 2000 and to 84 by $2010 .{ }^{6}$

Convergence in average net wealth between countries can be analysed referring to the concept of “international inequality”, which is particularly apt at detecting processes of convergence/divergence between nations (Milanovic, 2005). Note that the concepts of "global" and "international" inequality differ because of the methods, not because of the territorial coverage, which in Table 5.8 is kept constant across measures. In the unweighted version, international wealth inequality is calculated on the average net wealth of each country, without regard for relative population size and without taking into account within-country inequality. As shown in Table 5.8, international wealth inequality among the four Western countries declines steadily from 1870 to 2010, until it reaches almost perfect "equality". The same trend is found when looking at the population-weighted version of the index. If we apply the same measure to all countries for which we have information we get more erratic results which, again, simply reflects sharp changes in the coverage of the database across time - hence we report "world” measures from 1960 only, which are more reliable due to better territorial coverage.

\footnotetext{
${ }^{5}$ From 1870 to 1990 , the share of the richest $10 \%$ declines from $83 \%$ to $65 \%$.

${ }^{6}$ From 2000 to 2010 , the share of the richest $10 \%$ grows from $70 \%$ to $75 \%$.
} 
Figure 5.1. Global we alth distributions
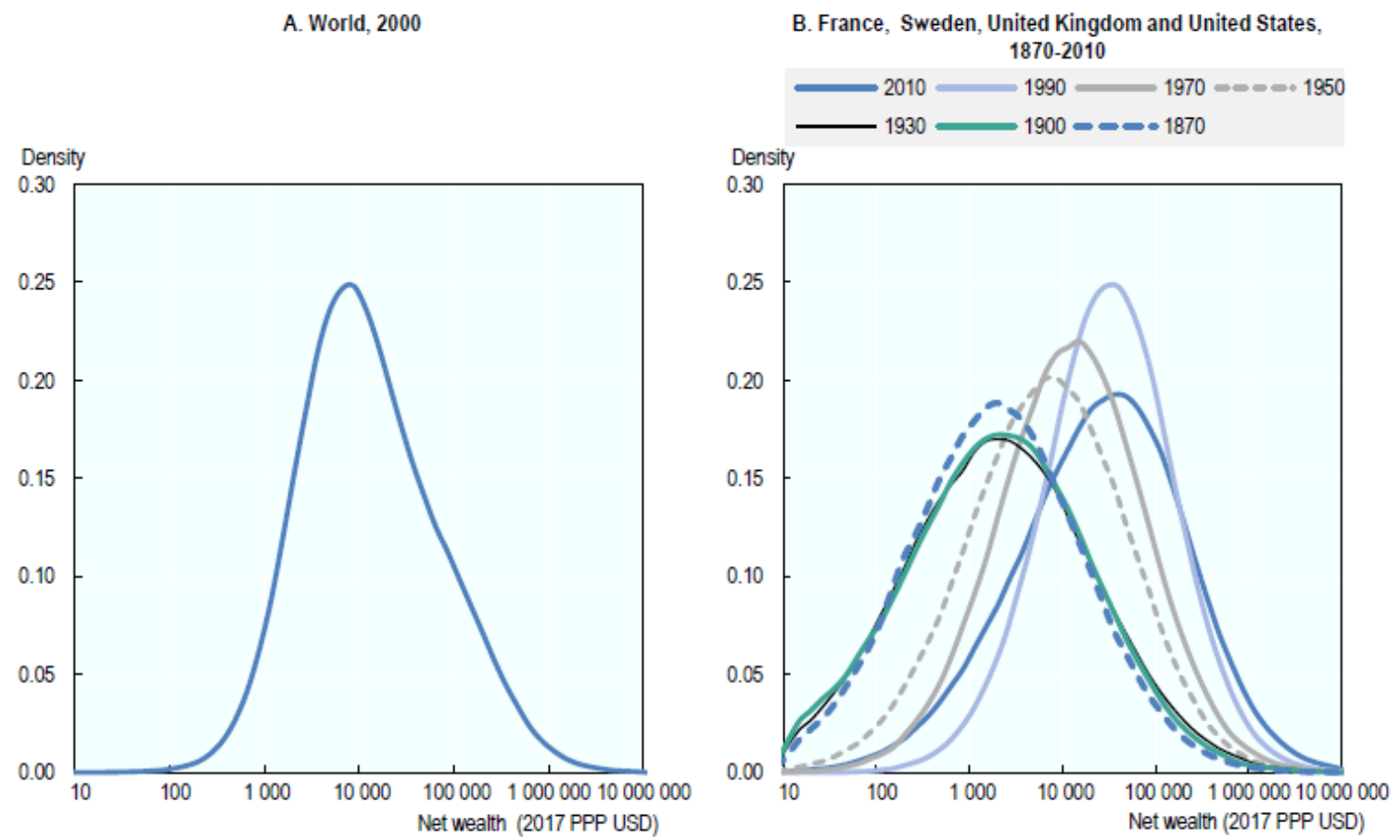

Note: For an assessment of data quality, see Table 5.2, Table 5.3 and Table 5.4.

Source: Clio-Infra, www.clio-infra.eu.

StatLink 2 https://stat.link/7h190r

The same problem with coverage applies to one final measure: the simple average of Gini levels. While in Table 5.8 the countries considered for each year are kept constant across measures, the simple average of Gini levels could cover a larger number of countries compared to our concept of global inequality, as it does not require information about net wealth. The "World Gini" calculated on all the countries for which we have the relevant information is shown in Table 5.7. 
Table 5.8. Average Gini, international inequality and global inequality, 1820-2010

\begin{tabular}{|c|c|c|c|c|c|c|c|c|c|c|}
\hline & \multicolumn{2}{|c|}{$\begin{array}{l}\text { Average Gini } \\
\text { (population } \\
\text { weighted) }\end{array}$} & \multicolumn{2}{|c|}{$\begin{array}{l}\text { Average Gini } \\
\text { (population } \\
\text { unweighted) }\end{array}$} & \multicolumn{2}{|c|}{$\begin{array}{l}\text { International } \\
\text { inequality } \\
\text { (weighted) }\end{array}$} & \multicolumn{2}{|c|}{$\begin{array}{l}\text { International } \\
\text { inequality } \\
\text { (unweighted) }\end{array}$} & \multicolumn{2}{|c|}{$\begin{array}{c}\text { Global } \\
\text { inequality }\end{array}$} \\
\hline & World & $\begin{array}{l}\text { FRA, } \\
\text { SWE, } \\
\text { GBR, } \\
\text { USA }\end{array}$ & World & $\begin{array}{l}\text { FRA, } \\
\text { SWE, } \\
\text { GBR, } \\
\text { USA }\end{array}$ & World & $\begin{array}{l}\text { FRA, } \\
\text { SWE, } \\
\text { GBR, } \\
\text { USA }\end{array}$ & World & $\begin{array}{l}\text { FRA, } \\
\text { SWE, } \\
\text { GBR, } \\
\text { USA }\end{array}$ & World & $\begin{array}{l}\text { FRA, } \\
\text { SWE, } \\
\text { GBR, } \\
\text { USA }\end{array}$ \\
\hline 1820 & & 87 & & 86 & & & & & & \\
\hline 1850 & & 88 & & 87 & & & & & & \\
\hline 1870 & & 87 & & 88 & & 22 & & 29 & & 88 \\
\hline 1890 & & 87 & & 89 & & 15 & & 24 & & 89 \\
\hline 1910 & & 90 & & 91 & & 12 & & 20 & & 91 \\
\hline 1930 & & 91 & & 91 & & 10 & & 18 & & 91 \\
\hline 1950 & & 82 & & 84 & & 17 & & 25 & & 82 \\
\hline 1960 & 74 & 83 & 73 & 81 & 13 & 13 & 17 & 18 & 83 & 84 \\
\hline 1970 & 73 & 80 & 71 & 76 & 15 & 10 & 13 & 14 & 75 & 81 \\
\hline 1980 & 60 & 76 & 68 & 70 & 61 & 10 & 20 & 17 & 86 & 77 \\
\hline 1990 & 60 & 74 & 68 & 70 & 63 & 8 & 29 & 15 & 84 & 76 \\
\hline 2000 & 64 & 79 & 70 & 78 & 55 & 8 & 22 & 16 & 82 & 80 \\
\hline 2010 & 74 & 83 & 72 & 75 & 37 & 1 & 18 & 5 & 80 & 84 \\
\hline
\end{tabular}

Note: For an assessment of data quality, see Table 5.3 and Table 5.4. Table 5.8 includes all the countries for which we also had information about net wealth. Consequently, the table covers a smaller group compared to Table 5.7, leading to some slight differences in the value of the "World" average between this table and Table 5.8 .

StatLink 2 https://stat.link/t3xbv9

\section{Correlation with GDP per capita}

Figure 5.2 gives a general picture of the relationship between GDP per capita and wealth inequality over time and across countries. From 1820 to 1840, wealth inequality is only very weakly correlated with GDP per capita. From 1850 onwards, the correlation becomes stronger and it is positive: richer countries have a higher wealth inequality than poorer ones. Nevertheless, after World War I the 
relationship stops increasing and, although remaining positive until 2010. By then it is even weaker than in the first half of the 19th century.

Figure 5.3 shows the correlation between GDP per capita and the Gini index of wealth inequality for all countries. The three graphs correspond to three different periods. The first panel includes observations for the period before 1930, the second panel describes the correlation from 1950 to 1970, and the third refers to the period from 1980 to 2010.

For the first period, the correlation between GDP per capita and wealth inequality is positive for those countries with a GDP per capita less than USD 8 000; the correlation turns negative for countries with GDP per capita above that level. During the 1950s and 1970s, the relationship is slightly negative and turns positive only for the highest-income countries. However, there are very few observations in the bottom and top GDP region. For the last period, the relationship is positive until USD 9 000, it turns negative until USD 24 000, and then it becomes positive again. Due to the already-discussed limitations in the available information, the number of countries differs across period, which might affect our results.

Figure 5. 2. Correlation between Gini coefficient of wealth ine quality and GDP per capita, 1820-2010

Pearson correlation coefficient

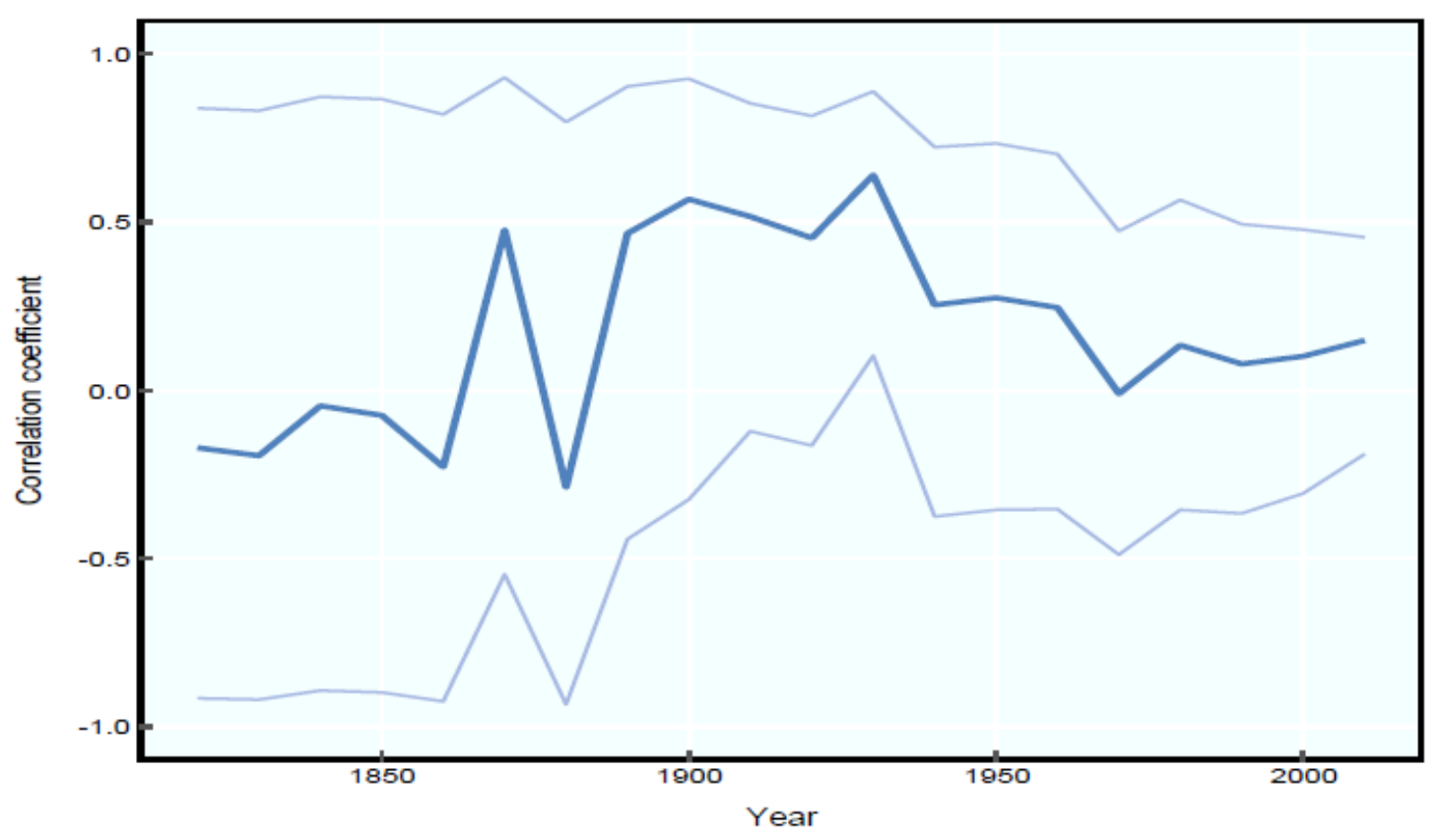


Note: The thick and thin lines correspond to the Person correlation coefficient and the 95\% confidence interval, respectively. For an assessment of data quality, see Table 5.3 and Table 5.4.

StatLink 2 https://stat.link/8oprm6

The overall conclusion is that there is no obvious and automatic correlation between GDP per capita and the change in wealth inequality in the period 1820-2010 - which confirms what has been argued for the pre-industrial period (1500-1800), when trends in wealth (and income) inequality have been reported to be largely unrelated to GDP (Alfani, 2015; Alfani, 2019; Alfani and Ryckbosch, 2016). Overall, our findings confirm the view that simple "Kuznetsian" explanations are not sufficient to explain long-term inequality trends (Alfani, 2019; Lindert, 2000; Vecchi and Amendola, 2017). Instead, we need to explore a broader range of causal factors beyond GDP change, embrace complexity in explanations, and pay great attention to context. An example of this approach is the recent masterful study of inequality in the United States from 1700 until today by Lindert and Williamson (2016).

\section{Priorities for Future Research}

The current availability of data about wealth inequality - in both contemporary and past societies - is far from satisfying. Even in comparison with data we have regarding income inequality, which is also surely not adequate for current research needs, wealth fares significantly worse. For many areas of the world, there is no information from before the last few decades, and for many countries we have no information even for recent years. To some degree, this reflects the nature of many national fiscal systems, which today weigh much more on income than on wealth - hence generating an inferior amount of useful information about the latter. ${ }^{7}$ But to this we have to add that research long neglected wealth in favour of income due to ideas about the long-run drivers of inequality growth that were probably misguided (chiefly, the view that wealth inequality is of only minor importance in determining total income inequality in the long run), as clearly exposed by many recent studies (Alfani, 2019; Lindert and Williamson, 2016; Piketty, 2014; Piketty, 2015; Roine and Waldenström, 2015).

\footnotetext{
7 This is also why, paradoxically, for a growing number of countries, especially but not limited to Europe, we now know more about wealth inequality before 1820 than after such date: as income taxes replaced older taxes based on real estate and other wealth components.
} 
Figure 5.3. Correlation between the Gini coefficient of wealth ine quality and GDP per capita in three time periods, 1820-2010

Semi-logarithmic scale
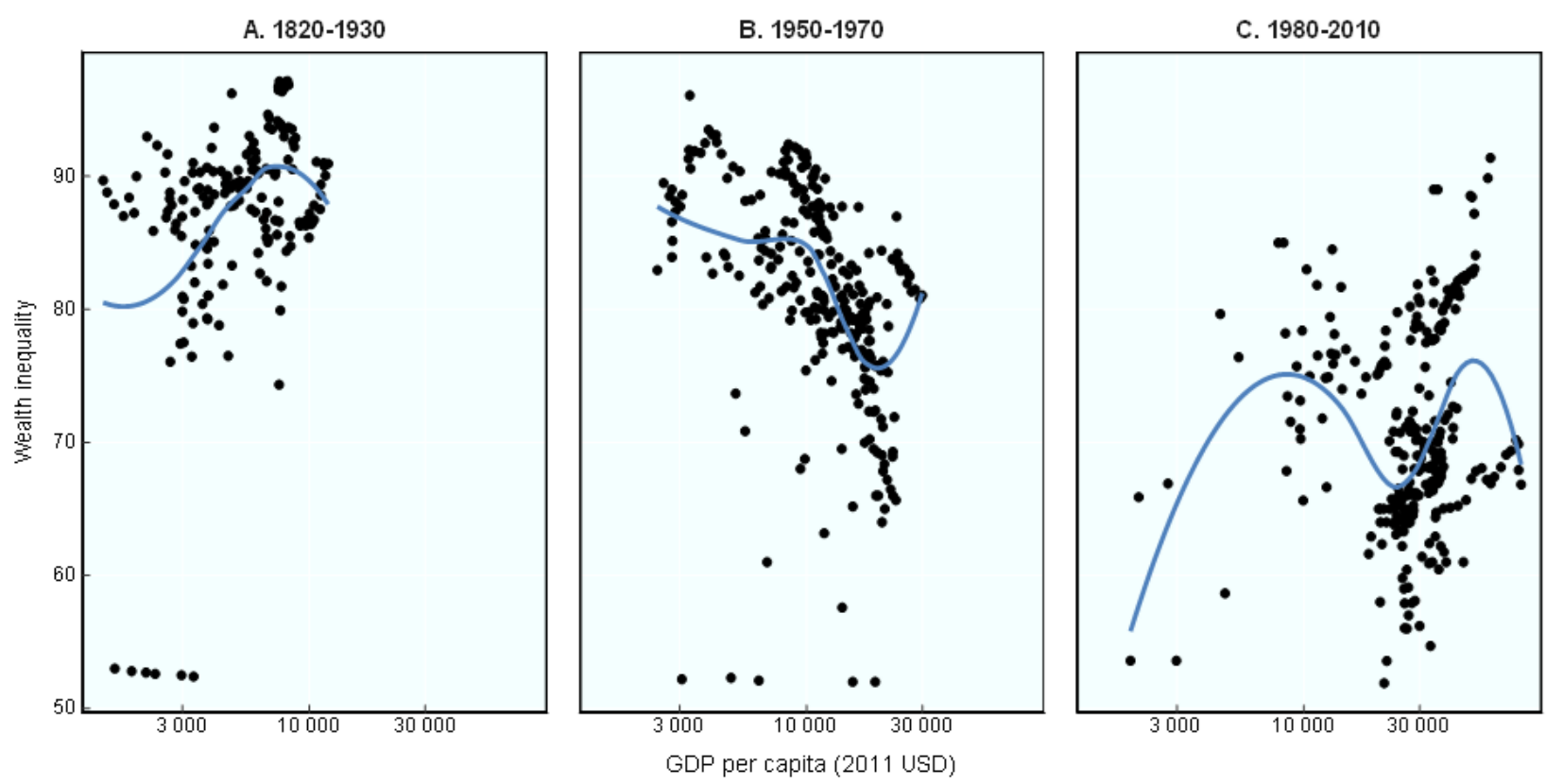

Note: Gini coefficient and GDP per capita at 2011 PPPs. The grey area around the correlation coefficient (shown as the blu line) corresponds to the confidence interval. Black dots corresponds to country estimates. For an assessment of data quality, see Table 5.3 and Table 5.4. This figure is based on all available annual information, not just the data included in Table 5.5. General patterns do not change when limiting the analysis to the countries in Table 5.5.

StatLink 2 https://stat.link/c16mhj

In the current world, characterised by growing inequality of both income and wealth, questions about the causes, and about the very nature and the potential consequences, of distributional change have acquired high societal relevance. But to answer such questions, we need more and better data. This need is further strengthened by the fact that recent research highlights how levels and trends of economic inequality cannot be “deduced” from trends in other variables, like GDP per capita, but must be measured as directly as possible. In particular, recent historical evidence provides strong support for the view that inequality growth cannot be simply considered a side effect of increasing prosperity (Alfani, 2019). In the foreseeable future, it seems probable that the area of the world for which the 
availability of data on the distribution of wealth will grow at the quickest pace is Europe, partly due to the relative abundance of useful historical sources and, even more, thanks to the many research groups that have risen to the challenge. This is undoubtedly a positive development, but the other side of the coin is that more will need to be done to better integrate other world areas - particularly Africa and Asia - into the broader picture. 


\section{References}

Alfani, G. (2019), "Wealth and income inequality in the long run of history”, in Diebolt, C. and M. Haupert (eds.), Handbook of Cliometrics, Springer International Publishing.

Alfani, G. (2017), "The rich in historical perspective. Evidence for preindustrial Europe (ca. 13001800)”, Cliometrica, Vol. 1/3, pp. 321-348.

Alfani, G. (2015), "Economic inequality in northwestern Italy: A long-term view (fourteenth to eighteenth centuries)”, The Journal of Economic History, Vol. 75/4, pp. 1058-1096.

Alfani, G. and F. Ammannati (2017), "Long-term trends in economic inequality: The case of the Florentine State, c. 1300-1800”, The Economic History Review, Vol. 70/4, pp. 1072-1102.

Alfani, G. and M. Di Tullio (2019), The Lion's Share. Inequality and the Rise of the Fiscal State in Preindustrial Europe, Cambridge University Press.

Alfani, G. and W. Ryckbosch (2016), "Growing apart in early modern Europe? A comparison of inequality trends in Italy and the Low Countries, 1500-1800”, Explorations in Economic History, Vol. 62, pp. 143-153.

Alvaredo, F.; A. Atkinson and L. Chancel (2016), "Distributional national accounts (DINA) guidelines: Concepts and methods used in WID.world”, WID. World Working Paper,No. 2.

Alvaredo, F., A. Atkinson and S. Morelli (2018), "Top wealth shares in the UK over more than a century”, The Journal of Public Economics, Vol. 162, pp. 26-47.

Alvaredo, F. et al. (2013), "The top 1 percent in international and historical perspective", The Journal of Economic perspectives, Vol. 27/3, pp. 3-20.

Atkinson, A. (1980), Wealth, Income and Inequality, Oxford University Press.

Atkinson, A., T. Piketty and E. Saez (2011), “Top incomes in the long run of history”, The Journal of Economic Literature, Vol. 49/1, pp. 3-71.

Balestra, C. and R. Tonkin (2018), "Inequalities in household wealth across OECD countries: Evidence from the OECD Wealth Distribution Database”, OECD Statistics Working Papers, No. 2018/01, OECD Publishing, Paris, https://dx.doi.org/10.1787/7e1bf673-en.

Bengtsson, E. et al. (2018), "Wealth inequality in Sweden, 1750-1900”, The Economic History Review, Vol. 3, pp. 772-794.

Borgerhoff Mulder, M. et al. (2009), "Intergenerational wealth transmission and the dynamics of inequality in small-scale societies”, Science, pp. 682-688. 
Brandolini, A. et al. (2004), Household Wealth Distribution in Italy in the 1990s, Banca d'Italia.

Canbakal, J., A. Filiztekin and S. Pamuk (2018), Inequality of Income and Wealth in the Ottoman Empire, 1500-1800, paper given at the World Economic History Congress (Boston, 30 July-3 August 2018).

Coşgel, M. and B. Ergene (2012), "Inequality of wealth in the Ottoman Empire: War, weather, and long-term trends in eighteenth-century Kastamonu”, The Journal of Economic History, Vol. 72/2, pp. 308-331.

Credit Suisse (2017), Global Wealth Databook 2017, https://www.credit-suisse.com/aboutus/en/reports-research/global-wealth-report.html (accessed on 14 January 2020).

Credit Suisse (n.d.), The Global Wealth Reports, https://www.credit-suisse.com/aboutus/en/reports-research/global-wealth-report.html (accessed on 12 January 2020).

Davies, J., R. Lluberas and A. Shorrocks (2017), "Estimating the level and distribution of global wealth, 2000-2014”, The Review of Income and Wealth, Vol. 63/4, pp. 731-759.

Davies, J. et al. (2010), "The level and distribution of global household wealth", The Economic Journal, Vol. 121/551, pp. 223-254.

Davies, J. and A. Shorrocks (2000), The Distribution of Wealth, Elsevier.

Di Matteo, L. (2018), The Evolution and Determinants of Wealth Inequality in the North Atlantic Anglo-Sphere, 1668-2013. Push and Pull, Springer.

Gabbuti, G. and S. Morelli (2019), Inheritances and the Concentration of Personal Wealth in Italy from Unification to the Great War (1862-1915), Mimeo.

Heilbroner, R. (2008), Wealth, Palgrave Macmillan.

Ihle, D. and A. Siebert-Meyerhoff (2017), "The older, the richer? A decomposition of wealth inequality by age subgroups", CAWM Discussion Paper, Vol. 97.

Kuznets, S. (1955), "Economic growth and income inequality", The American Economic Review, Vol. 45, pp. 1-28.

Lindert, P. (2000), Three centuries of inequality in Britain and America, Elsevier.

Lindert, P. (1991), "Toward a comparative history of income and wealth inequality", in Income Distribution in Historical Perspective, Cambridge University Press.

Lindert, P. (1986), “Unequal English wealth since 1670”, The Journal of Political Economy, Vol. 94/6, pp. 1127-62.

Lindert, P. and J. Williamson (2016), Unequal Gains. American Growth and Inequality Since 1700, 
Princeton University Press.

Milanovic, B. (2005), Worlds Apart. Measuring International and Global Inequality, Princeton University Press.

Nicolini, E. and F. Ramos Palencia (2016), "Comparing income and wealth inequality in preindustrial economies: Lessons from 18th-century Spain”, EHES, Working Papers, Vol. 95.

OECD (2015), In It Together: Why Less Inequality Benefits All, OECD Publishing, Paris, https://dx.doi.org/10.1787/9789264235120-en.

OECD (2013), OECD Guidelines for Micro Statistics on Household Wealth, OECD Publishing, Paris, https://dx.doi.org/10.1787/9789264194878-en.

OECD (n.d.), OECD Wealth Distribution Database, https://stats.oecd.org/Index.aspx?DataSetCode=WEALTH.

Paglin, M. (1975), "The measurement and trend of inequality: A basic revision", The American Economic Review, Vol. 65, pp. 598-609.

Piketty, T. (2015), "Putting distribution back at the center of economics: Reflections on capital in the twenty-first century”, The Journal of Economic Perspectives, Vol. 29/1, pp. 67-88.

Piketty, T. (2014), Capital in the Twenty-First Century, Belknap Press of Harvard University Press.

Piketty, T., G. Postel-Vinay and J. Rosenthal (2014), "Inherited vs self-made wealth: Theory \& evidence from a rentier society (Paris 1872-1927)”, Explorations in Economic History, Vol. 51, pp. 21-40.

Piketty, T., G. Postel-Vinay and J. Rosenthal (2006), "Wealth concentration in a developing economy: Paris and France, 1807-1994”, The American Economic Review, Vol. 96/1, pp. 236-256.

Prados de la Escosura, L. (2007), Inequality and poverty in Latin America: A long-run exploration, M.I.T. Press.

Roine, J. and D. Waldenström (2015), Long run trends in the distribution of income and wealth, Elsevier, https://www.sciencedirect.com/handbook/handbook-of-inc omedistribution/vol/2/suppl/C (accessed on 14 January 2020).

Sahlins, M. (1974), Stone Age Economics, Routledge.

Scheidel, W. (2017), The Great Leveller: Violence and the Global History of Inequality from the Stone Age to the Present, Princeton University Press. 
Schneider, M., M. Pottenger and J. King (2016), The Distribution of Wealth-Growing Inequality?, Edward Elgar Publishing.

Sutch, R. (2016), The Accumulation, Inheritance, and Concentration of Wealth during the Gilded Age: An Exception to Thomas Piketty's Analysis.

van Zanden, J. et al. (2014), How Was Life?: Global Well-being since 1820, OECD Publishing, https://doi.org/10.1787/9789264214262-en.

Vecchi, G. and N. Amendola (2017), Inequality, Oxford University Press.

WID.world (n.d.), The World Inequality Database, https://wid.world/ (accessed on 12 January 2020). 